\title{
鼻アレルギー患者の手術療法選択に対する 音響鼻腔計測法の有用性
}

\author{
東邦大学医学部耳鼻咽喉科学第 2 講座 \\ 大木 幹文, 伊藤 浩一, \\ 川野まどか, 大 越 俊夫
}

\section{Acoustic Rhinometry Usefulness in Choosing Surgical Therapy in Patients with Allergic Rhinitis}

\author{
Motofumi Ohki, Koichi Ito, Madoka Kawano, \\ Toshio Ogoshi
}

$2^{\text {nd }}$ Department of Otorhinolaryngology, Toho University, Tokyo

\begin{abstract}
Nasal obstruction is an important symptom in allergic rhinitis. Several types of nasal surgery instruments have been reported useful in reducing nasal obstruction. Structural problems such as deviation of the nasal septum may, however, also influence nasal obstruction often necessitating septoplasty. This makes it important to clarify factors in nasal obstruction before deciding how to treat allergic rhinitis.

Acoustic rhinometry, introduced by Hilberg (1989) measures the degree of openness of the nose or its parts. Several authors have reported the responsiveness of nasal patency to methacholine provocation with acoustic rhinometry.

We measured the change in nasal patency and nasal responsiveness to acoustic rhinometry before nasal surgery in patients with allergic rhinitis and studied surgical options in allergic rhinitis.

Subjects were 30 patients with perennial allergic rhinitis and mild or severe nasal obstruction. Of these, 11 underwent inferior turbinectomy and septoplasty with the inspection of nasal symptoms and radiographic examination. The 19 underwent conservative therapy. Minimum nasal cross- ${ }^{-}$sectional area and nasal response to methacholine nasal spray were compared between groups using an acoustic rhinometer (RHIN2100 Rhinometrics co. Denmark). Measurement with acoustic rhinometry was also studied after a topical nasal decongestant was administered.

We found values and parts of minimum nasal cross-sectional area in both groups to statistically the same. We found the difference in decongested minimum cross-sectional area between the left and right sides of the nose was useful in evaluating the degree of deviation in the nasal septum. The narrowed cross-sectional area in the surgical group was statistically wider than in the non-surgical group $(\mathrm{p}<005)$. Hyperresponsiveness to methacholine nasal provocative test did not differ between groups in our study. These results suggest, however, investigation of the effect of both mucosal and structural factors is important in deciding allergic rhinitis treatment.
\end{abstract}


In conclusion, evaluation of the value and wideness of cross-sectional area is useful in determining nasal surgery in patients with allergic rhinitis.

Key words : Acoustic rhinometry, Allergic rhinitis, Deviation of nasal septum, Septoplasty and turbinectomy

\section{1. はじめに}

近年, 免疫組織学の進歩により, 鼻アレルギーの発症 機序は明らかになりつつある。その結果, 抗ヒスタミン 剤をはじめ, 抗ロイコトリエン剤, 抗トロンボキサン $\mathrm{A}_{2}$ 剤など種々の作用を持った薬物が開発され, その治療は 有効性を増してきている。しかしながら，アレルギー反 応により高度鼻閉を生じた症例の改善には, 様々な手法 により手術療法が加えられている”。鼻閉に影響を与え る因子は大きく粘膜性と構造性に分けることが可能であ $\eta^{2.3}$ ，この 2 つの因子による影響の度合が症例により異 なるため, 生体内外の環境の変化に対する鼻閉の恒常的 な改善は, 必ずしも容易ではない。従って, 鼻閉を伴う 鼻アレルギーの治療の選択においてもアレルギー反応に より腫脹した鼻粘膜の炎症の改善だけで症状が緩解する とは限らない。このような症例では鼻腔構造の改善手術 を付加する必要がある。鼻アレルギーの反応性の克進に よる鼻粘膜の腫脹を客観的に評価し，その治療法にたい する検討は, これまでにも報告されているが, 鼻腔構造 が鼻アレルギーの病態にどれほど影響するかについて客 観的診断法で報告されたものは極めて少ない。

これまで手術前後で鼻腔の通気性を客観的に評価する 方法としては鼻腔通気度計による鼻腔抵抗の測定法が広 く知られているが， Hilberg'によより紹介された音響鼻 腔計測法 (Acoustic Rhinometry) も優れた評価法であ り本邦でも薬事承認された。鼻アレルギー患者に対して 本法により計測をすると, コリン作動物質であるメサコ

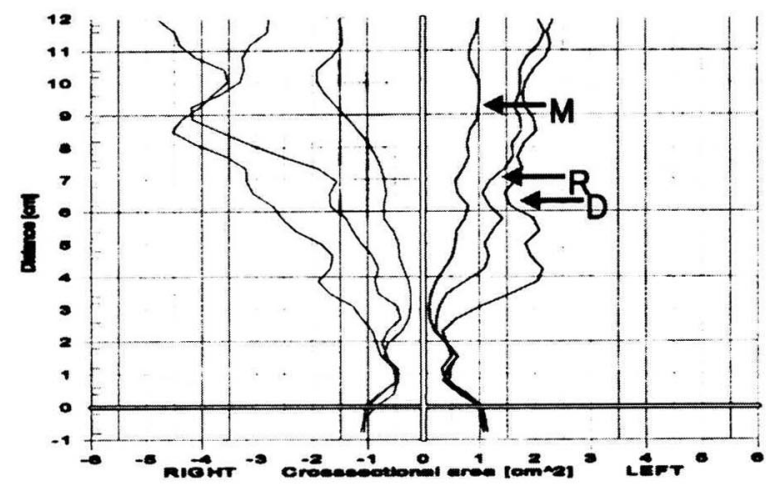

\section{$R$ : 安静時 $M$ :メサコリン噴霧 $D$ :血管収縮剤噴霧}

図 1 鼻アレルギー患者の測定曲線
リンと血管収縮剤の噴霧によって, 鼻腔開存性は変動す る ${ }^{6)}$ (図 1 )。特に収縮剤噴霧後に得られる曲線は鼻粘膜 収縮により鼻腔構造を反映した測定曲線であると考えら れ, 左右の測定曲線の比較から, 鼻腔構造の左右の差異 が鼻疾患に影響を与えているか否か診断する事が可能と 思われる7。

そこで今回，下鼻甲介手術に鼻中隔矯正術を加えて手 術を施行した症例と，保存的治療法を選択した症例につ いて放射線診断と音響鼻腔計測法から，事前の治療法選 択の可能性について検討を試みた。

\section{2. 対象および方法}

対象は，鼻閉を主訴に東邦大学大橋病院耳鼻咽喉科を 受診し, 鼻症状と鼻腔所見から鼻アレルギーガイドライ ン診断基準 ${ }^{81}$ にて中等度以上の通年性鼻アレルギーと診 断された患者 30 名である。そのうち放射線顔面断層撮影 を加え, 複数の医師の所見と患者へのインフォームドコ ンセントから手術適応と診断し, 鼻中隔矯正術と下鼻甲 介広汎切除術を施行したものが11名（男性 5 名，女性 6 名。年齢17-49歳。平均 26.3 歳), 非手術症例が19名（男 性 7 名，女性 12 名。年齢18-51歳。平均 28.9 歳)である。 治療前の生理学的解析にはコントロールとして正常成人 10 名 (男性 3 名, 女性 7 名。年齢22-36歳。平均 24.5 歳) も同様な測定を行った。

放射線断層撮影の検討は鼻尖より $2 \mathrm{~cm}$ から後方 $7 \mathrm{~cm}$ まで $5 \mathrm{~mm}$ 間隔にて撮影し，骨部あるいは軟骨部におけ る彎曲の頂点と正中線との距離を彎曲度として計算し た。彎曲のピークの位置は鼻尖部よりの距離を計算する

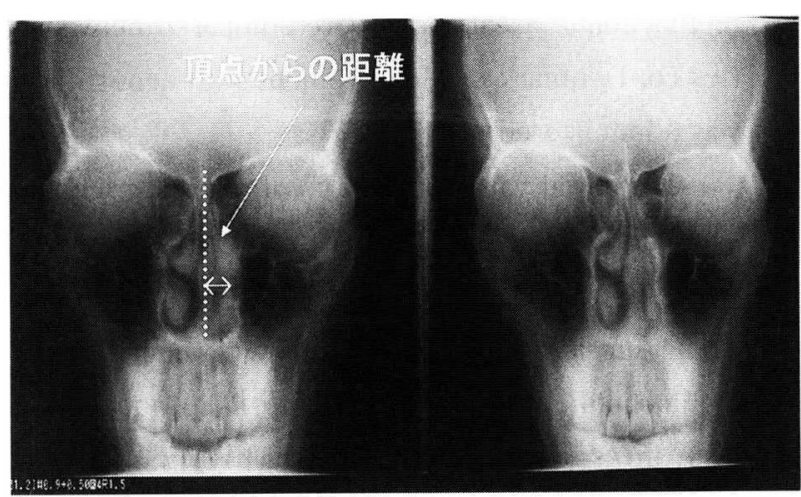

図 2 断層撮影による鼻中隔彎曲の検討 


\section{こととした。(図 2 )}

生理学的検討では，まず15分の安静後に坐位にて Acoustic Rhinometer (RHIN2100, SRE 社製, デンマー ク）を用いて鼻腔開存性を測定し，さらに鼻粘膜の反応 性の観察を目的として定量噴霧器を用いて塩化メサコリ ン溶液 $100 \mu \mathrm{g}$ を両側鼻腔に噴霧し 5 分後の鼻腔開存性 の変化をこれまでの報告と同様に, 変化率 =メサコリン 噴霧後 - 血管収縮剂噴霧後 $/$ 噴霧前 - 血管収縮剂噴霧後 として計算しだ”。応性の評価はこれまでの検討を参 考に，正常者は全例 $25 \%$ 以下であったことから，変化率 $25 \%$ 以下 0 (反応無し)，25-35\%を1（軽度反応あ り), $35 \%$ 以上を 2 (反応あり）と便宜上スコア化して 解析した。次に，鼻鏡所見および音響鼻腔計測法により 十分鼻粘膜の反応性が改善されたのを確認の後, 同種の 噴霧器により血管収縮剤を噴霧し, その10分後の鼻腔開 存性の測定から鼻粘膜の腫脹と鼻腔構造の関係を検討し た。

測定項目として測定曲線の 1 番目の notch（I-notch） 以後における最小鼻腔断面積と前鼻孔からの距離を計算 した。又, 鼻中隔彎曲による形状の評価が可能か否かに ついて, 測定曲線そのものの特徽についても検討するこ ととした。

個々の統計学的解析は $\mathrm{t}$ 検定にて行い, $\mathrm{p}<0.05$ を有 意差ありとした。

\section{3. 結 果}

\section{(1)放射線断層撮影の比較}

まず，放射線断層撮影により手術例と非手術例の比較 を行った。彎曲のピークの位置は手術例が有意差を持っ て前方に存在していた（p<0.05）。（表 $1 ）$ また, 正中 線からの彎曲の距離も手術例が $5.9 \pm 2.8 \mathrm{~mm}$, 非手術例 が $4.2 \pm 2.5 \mathrm{~mm}$ と手術例が有意に高い傾向がみられた $(\mathrm{p}<0.05)$ 。すなわ手術例の方に彎曲が強いことが示

表 1 放射線断層撮影の比較

\begin{tabular}{llcl} 
& 手術例 $(\mathrm{N}=11)$ & 非手術例 $(\mathrm{N}=19)$ & \\
\hline 彎曲ピークの位置 & $2.6 \pm 0.3(\mathrm{~cm})$ & $3.4 \pm 0.5$ & $\mathrm{P}<0.05$ \\
正中からの距離 & $5.9 \pm 2.8$ & $4.2 \pm 2.5$ & $\mathrm{P}<0.05$
\end{tabular}

表 2 音響鼻腔計測法の比較

\begin{tabular}{lccc} 
& 手術例 $(\mathrm{N}=11)$ & 非手術例 $(\mathrm{N}=19)$ & \\
\hline 鼻腔断面積最小の位置 & $2.44 \pm 0.54(\mathrm{~cm})$ & $2.61 \pm 0.27$ & N.S. \\
最小鼻腔断面積 (安静時) & $0.29 \pm 0.17(\mathrm{~cm} 2)$ & $0.31 \pm 0.16$ & N.S. \\
最小鼻腔断面積 (収縮後) & $0.46 \pm 0.15(\mathrm{~cm} 2)$ & $0.49 \pm 0.15$ & N.S. \\
断面積左右差 (収縮後) & $0.31 \pm 0.19(\mathrm{~cm} 2)$ & $0.20 \pm 0.10$ & $\mathrm{p}<0.05$ \\
メサコリン過敏性 & $1.5 \pm 0.5$ & $1.5 \pm 0.6$ & N.S.
\end{tabular}

唆される。

\section{(2) 音響鼻腔計測法による比較}

手術例・非手術例について最小鼻腔断面積を示す部位 を比較検討した。その結果, 両者には有意差はなく，入 口部より $2.5 \mathrm{~cm}$ 前後に存在しており，有意差は認めら れなかった。（表 2 ）これは，鼻中隔彎曲をともなった 症例でも下鼻甲介前端付近が通気性に最も関与している ことが示唆される。従って，断層撮影からみた彎曲部位 とは, 相関係数 $\mathrm{R}=0.145, \mathrm{p}=0.45$ で有意な相関は認 められなかった。また, 最小鼻腔断面積においては安静 時, 血管収縮剤噴霧後とも有意差を認めず, 音響鼻腔計 測法において手術例と非手術例で有意差を認めたのは血 管収縮剤噴霧後の左右差であった（ $<<0.05 ） 。$

メサコリンによる鼻粘膜反応性をスコア化して比較検 討した。しかしながら手術例，非手術例とも有意差は認 められなかった。すなわち，鼻粘膜病態の変化に差が認 められなかった。

次に, 鼻中隔彎曲症患者の測定曲線の特徴を比較して みた。すると，鼻中隔凸側の曲線では，（図 3 ）の様に 本来の 2 番目の notch (c-notch) が明確ではなく彎曲 の影響で狭小化を示す範囲が広い特徴が認められた。

最小鼻腔断面積の部位前後 $5 \mathrm{~mm}$, 後方 $10 \mathrm{~mm}$ の断面

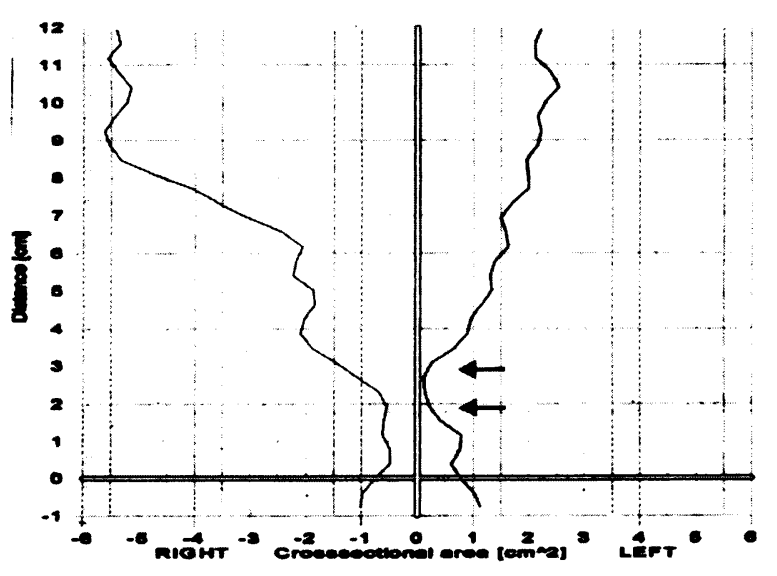

図 3 鼻中隔彎曲症患者の測定曲線

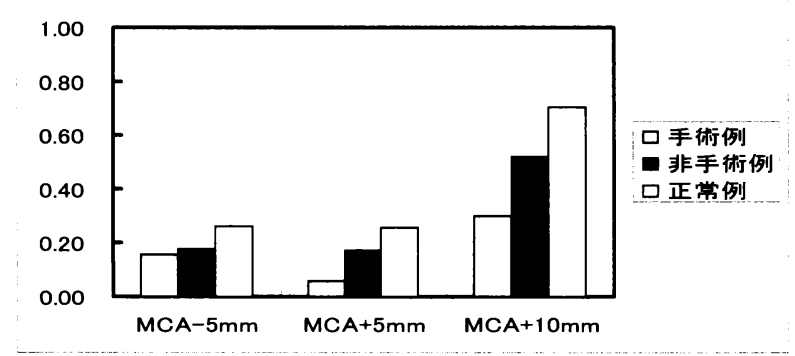

MCA-5: N.S. MCA+5, MCA+10: $\mathrm{P}<0.05$ (ANOVA)

図 4 鼻中隔彎曲症患者における鼻腔狭小化の範囲 
積と最小鼻腔面積との差 $\mathrm{MCA}-5, \mathrm{MCA}+5, \mathrm{MCA}+10$ を求めた。その結果を正常者, 手術例, 非手術例で分散 分析にて比較検討すると, 前方 $5 \mathrm{~mm}$ では 3 群間で有意 差はないものの, 後方では $5 \mathrm{~mm}$, さらには $10 \mathrm{~mm}$ まで も手術例では最小鼻腔断面積との差が有意に小さいこと が解った $(\mathrm{P}<0.05)$ 。(図 4$)$

\section{4. 考 察}

鼻アレルギーの鼻閉の治療はこれまでも大きな課題と なっている。近年, ロイコトリエン拮抗剤やトロンボキ サン拮抗剤などの開発により, 有効な薬物療法も認めら れるようになった。しかしながら，鼻閉に影響を与える 因子としては鼻アレルギー反応による鼻粘膜腫脹などに 認められるような粘膜性因子ばかりではなく，鼻中隔彎 曲など構造性因子による場合もある。多くの症例では, この構造性因子と粘膜性因子がお互いに影響してい る7”。従って, 鼻アレルギーの治療計画を立てて行くに は，事前に客観的な評価をしていく必要がある。これま でこのような症例ではガイドラインダにも記載されてい るように, 鼻腔所見などから適宜, 鼻中隔矯正術を付加 してきたのが現状である。しかしながら，島田ら"は鼻 中隔彎曲は本邦では $85 \%$ 以上のものに存在していると報 告しており，また，Ecclesのグループロ では鼻閉を訴 える患者のほとんどが鼻腔構造の異常を自覚していない と報告している。その原因のひとつとして nasal cycle により彎曲の凹側にも鼻粘膜の腫脹を来すことがあり鼻 閉側が明確で無くなる点を指摘している。

一方，レーザー，あるいはアルゴンプラズマなど，出 血量が比較的少なく, 外来で容易に可能な下鼻甲介手術 も有用性の報告が多く散見されるようになった”。しか しながら,これらの治療法も鼻中隔彎曲などの構造的な 問題から, 期待した効果が得られない症例も認めるよう で, 適宜鼻中隔矯正術を付加しているのも事実のようで ある"1。このような観点から，保存的治療に抵抗をする ような鼻アレルギー患者に対して，どのような外科手術 を選択すべきかについて事前診断の必要性が認められ る。今回, 私達の施設で従来の診療から治療法を選択し た外科手術症例と非手術例について, 改めて放射線学 的, 生理学的解析を行い, 将来外科的適応基準の作成が 可能か否かを検討してみた。放射線学的解析法は奇しく も Buyukertan ${ }^{121}$ と同様であった。結果として手術例の 方に彎曲が強いことが解り，この事実は前鼻鏡所見が術 式選択に反映しているものと考えられた。

次に生理学的検討を行った。その結果は，これまでの 鼻腔通気度計を用いた鼻腔抵抗の測定から得られた結論
と同様に，音響鼻腔計測法においても血管収縮剤噴霧後 の開存性の左右差の大きいものに手術例が多かっ

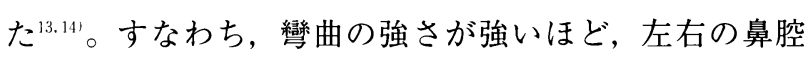
開存性に差が強く，鼻アレルギーの粘膜腫脹によって生 ずる鼻閉に影響を与えると考えられた。従って，彎曲の 診断には血管収縮剤噴霧後における左右の開存性の検討 が重要と思われた。しかしながら，Ecclesの言うよう に"1)，S 字状の彎曲では左右差が明確にならない症例も 認められた。これが従来の報告 ${ }^{15.16 !}$ でも，最小鼻腔断面 積などを用いた術前術後における鼻腔開存性の改善度の 評価にとどまっている理由と考えられる。音響鼻腔計測 法の一つの特徵は, 鼻腔開存性を測定曲線から視覚的に 評価できることにある。そこで鼻中隔彎曲の手術例と非 手術例を測定曲線から比較検討することを試みた。その 結果, 曲線で狭小化の範囲が大きい症例に手術例が有意 に多いことが解った。すなわち，手術を選択した症例は 彎曲の影響が鼻腔前後で広範囲に存在し，その結果鼻腔 開存性の狭小化の範囲が広いことであると考えられた。 Cole ら尚も述べているように, 鼻腔の通気性は最小鼻 腔断面積で決まると言われてきたが，内藤 ${ }^{181}$ は断面の構 造も影響を受けると報告している。今回の検討結果も彎 曲の範囲が前後に大きいことも実際の鼻呼吸には影響を 与えると思われる。範囲の変化を定量的に評価する手段 としては鼻腔容積が良いという意見もある ${ }^{19.211 。}$

しかしながら，国際標準化委員会ではこのような開存 性の変化をどの範囲での容積変化で評価するかについて は未だ基準を定めていない211。今後は鼻腔容積での検討 も加える必要があると思われる。

鼻アレルギーの病態の特徵は気道過敏性にある。 Malm ら ${ }^{221}$ は, 鼻疾患における負荷試験の重要性を指摘 しており，ヒスタミンや泠温といった非特異的刺激によ る負荷試験の有用性を指摘している。私達も非特異刺激 としてコリン作動物質であるメサコリンは, 鼻粘膜の過 敏性の評価に有益であると報告してきた ${ }^{231}$ 。Marque ら ${ }^{24}$ は音響鼻腔計測法を用いてメサコリンによる鼻粘膜反 応性の変化を観測しており，通年性鼻アレルギー患者は メサコリン点鼻により，20\%以上の鼻腔開存性の狭小化 を認めると述べている。そこで私達も, 鼻粘膜の反応性 についてメサコリン局所投与による負荷試験を行い, 比 較検討を行った。その結果では手術例と非手術例で有意 差を認めなかった。すなわち，手術を必要と認められた ものと認められなかったものとで，アレルギーによる鼻 粘膜病態の変化に差はなく, 極めて重症難治例だけが手 術適応になったわけではなかったことを意味する。しか しながら，治療方針の決定には鼻粘膜の反応性の検討も 
重要であり, 鼻閉に影響を与える粘膜性因子と構造性因 子との関連性について今後さらに検討が必要と思われ た。

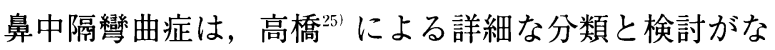
されている。また, 市村 ${ }^{26)}$ は, 鼻閉の鑑別には鼻中隔彎 曲の部位を詳細に検討すべきと提唱している。音響鼻腔 計測法では音波の直進性から, 上下を含めた立体的構造 まで評価できないが, 測定曲線を細かく解析すること で，客観的な手術適応基準を決められる可能性が示唆さ れた。今後はいくつかのパラメータの関連性を加えた検 討が必要と思われた。

\section{5. まとめ}

(1) 鼻閉を主訴として来院した患者に放射線診断と Acoustic Rhinometry から手術例, 非手術例を比較検討 した。

(2) 放射線診断では彎曲が前方に強い症例に手術例が 多かった。

(3) 音響鼻腔計測法では, 最小鼻腔断面積とその位置 で, 手術例, 非手術例の間に有意差は認められなかった。

(4) 彎曲の程度の評価には血管収縮剤噴霧による鼻腔 断面積の左右差の検討が有益であった。

(5) 測定曲線からは手術例において彎曲による鼻腔狭 小化の範囲が大きかった。

(6) 解析法を組み合わせることで, 手術適応診断の可 能性が示唆された。

本論文の要旨の一部は第41回日本鼻科学会総会（2002 年，広島）で口演した。

\section{参考文献}

1 ) 田部哲也：アレルギー性鼻炎の日㷌り手術. JOHNS 17 : 1293-1298, 2001.

2 ) Cody DR, Kern EB, Pearson BW : Ears Nose, and Throat. Year Book Medical Publishers Chicago, London 1981.

3 ) Broms P : Rhinomanometry III (Procedures and criteria for distinction between skeletal stenosis and mucosal swelling). Acta Otolaryngol (Stockh)94: 361-370, 1982.

4 ) 内藤健晴, 宮崎総一郎, 野中 聡：鼻腔通気度測定 法 (Rhinomanometry) ガイドライン。 日鼻誌 40 ： 327-331, 2001.

5 ) Hilberg O, Jackson AC, Swift DL, et al: Acoustic rhinometry: evaluation of nasal cavity geometry by acoustic reflection. J Appl Physiol 66 : 295-303, 1989.

6 ）大木幹文, 伊藤浩一, 石橋まどか, 他：鼻アレルギ 一治療評価における負荷試験の意義：Acoustic Rhinometry を用いた検討。 日鼻誌 $40 ： 260 ， 2001$.

7 ）大木幹文, 石橋まどか, 井上里可, 他: 正常成人お よび鼻アレルギー患者における Acoustic Rhinometry 測定曲線の比較. 日鼻誌 $39 ： 7-11,2000$.

8 ）馬場廣太郎 編：鼻アレルギー診療ガイドライン一 通年性鼻炎と花粉症一。ライフサイエンス社，東 京, 2002 .

9 ）島田和哉：鼻中隔彎曲と鼻閉. JOHNS 4：21-25, 1988.

10) Hanif J, Jawad SSM, Eccles R: A study to assess the usefulness of a portable spirometer to quantify the severity of nasal septal deviation. Rhinology 41 : 11-15, 2003.

11）佐藤公則：鼻アレルギーに対する内視鏡下レーザー 手術。耳鼻臨床 90：1009-1012，1997.

12) Buyukertan M, Keklikoglu N, Kokten G : A morphometric consideration of nasal deviations by people with paranasal complaints; a computed tomography study. Rhinology 41 : 21-24, 2003.

13）嵐裕治, 浜田利彦, 吉永正承, 他：鼻腔抵抗から 見た形態是正術の効果とその評価. 日鼻誌 $34 ： 45^{-}$ 49, 1989.

14）野本達夫：鼻内形態が鼻呼吸抵抗に及ぼす影響につ いての研究, 耳展 $32: 123-139,1989$.

15) Grymer LG, Hilberg O, Pedersen OF, et al: Acoustic rhinometry: Evaluation of the nasal cavity with septal deviations, before and after septoplasty. Laryngoscope 99 : 1180-1187, 1989.

16) Shemen L, Hamburg R: Preoperative and postoperative nasal septal surgery assessment with acoustic rhinometry. Otolaryngol Head Neck Surg 117 : 338-342, 1997.

17) Cole P, Haight JSJ, Love L, et al : Dynamic components of nasal resistance. Am Rev Respir Dis 132 : 1229-1232, 1985.

18）内藤健晴：鼻閉の客観化に関する研究の進歩．耳喉 頭頸 $72 ： 479-488,2000$.

19) Yamagiwa M, Hilberg O, Pedersen OF, et al : Evaluation of the effect of localized skin cooling on nasal airway volume by acoustic rhinometry. Am Rev Respir Disease 141 : 1050-1054, 1990. 
20) Djupesland P, PedersenOF : Acoustic rhinometry in infants and children. Rhinology Suppl 16:52-58, 2000 .

21) Hilberg $O$, Pedersen OF : Acoustic rhinomnetry : recommendations for technical specifications and standard operating procedures. Rhinology Suppl $16: 3-17,2000$.

22) Malm L, Gerth R, Bashert C: Guidelines for nasal provocations with aspects on nasal patency, airflow, and airflow resistance. Rhinology 38: 1-6, 2000.

23）臼井信郎, 吉野由紀子, 大木幹文：コリン反応性鼻 粘膜の鼻腔抵抗に及ぼすメサコリンの効果. 日鼻誌 $38: 27-32,1999$.

24) Marquez F, Sastre J, Hernandez G, et al : Nasal hy- perreactivity to methacholine measured by acoustic rhinometry in asymptomatic allergic and perennial nonallergic rhinitis. Am J Rhinol 14 : 251-256, 2000.

25）高橋 良：鼻中隔の成立と鼻中隔彎曲の成因につい て. 耳展 29 (補 2) : 94-216, 1986.

26）市村恵一：鼻閉の鑑別診断. JOHNS $4: 5-10$, 1988.

(2003年 5 月 12 日受稿, 2003 年 6 月 16 日受理)

別刷請求先 : 大木幹文

干153-8515 目黒区大橋 2-17-6

東邦大学医学部耳鼻咽喉科科学第二講座

Tel : 03-3468-1251 Fax : 03-3468-3970 